\title{
The Prehistoric Axe Factory at Sanganakallu-Kupgal (Bellary District), Southern India
}

Roberto Risch, Nicole Boivin, Michael Petraglia, David Gómez-Gras, Ravi Korisettar and Dorian Fuller

\section{Table of Contents}

- Summary

- Table of Contents

- List of Figures

- 1. The Geographical, Geological and Archaeological Context

- 2. The Petrographic Composition of the Hiregudda Sanganakallu Dolerite Dyke

- 3. Technical Organisation of Production

- 4. Socio-economic Organisation

- 5. Conclusions

- Acknowledgements

- Bibliography

- $\quad$ Search the text

(C) Internet Archaeology/Author(s) URL: http://intarch.ac.uk/journal/issue26/26/toc.html Last updated: Wed Jul 292009 


\title{
The Prehistoric Axe Factory at Sanganakallu-Kupgal (Bellary District), Southern India
}

\author{
Roberto Risch ${ }^{1}$, Nicole Boivin ${ }^{2}$, Michael Petraglia', David Gómez-Gras ${ }^{3}$, \\ Ravi Korisettar ${ }^{4}$, and Dorian Q. Fuller ${ }^{5}$
}

1. Departament de Prehistòria, Universitat Autònoma de Barcelona

2. School of Archaeology, University of Oxford. Email: nicole.boivin@rlaha.ox.ac.uk

3. School of Archaeology, University of Oxford

4. Department of History and Archaeology, Karnatak University

5. Institute of Archaeology, University College London

\section{Summary}

A 10-30m wide dolerite dyke on the northernmost of the complex of granite hills in the Sanganakallu-Kupgal area became one of the main sources of raw material for the production of stone axes in southern India during the late prehistoric period. At least three large hill settlements (several hectares each) were established in the hill complex, and one of them appears to have gradually developed into a large-scale production centre. Quarrying and axe flaking started around 1900 cal BCE, during the so-called Ashmound phase of occupation, and reached its maximum development between 14001200 cal BCE, when a large region of the south Deccan plateau might have been supplied with finished and half-finished products from Sanganakallu. Systematic archaeological excavation and survey carried out since 1997 in the SanganakalluKupgal area, including the dyke quarry itself, has yielded tens of thousands of production flakes, blanks and macro-lithic tools related to the flaking, pecking and polishing of the axes. The ongoing study of these materials permits us to gain insight into the organisation of production in this area from a temporal and spatial perspective. In view of the social and economic transformations taking place in the Deccan plateau during the second half of the second millennium BC, some key questions concern the relationship between intensification of production and the social division of labour between different working areas and settlements. 


\section{List of Figures}

Figure 1: The three hills of the Sanganakallu-Kupgal complex. In the foreground is Hiregudda, taken from Area $\mathrm{C}$, where quarrying of the upper reaches of the dolerite dyke was carried out, and looking down onto Area A, where stone tool manufacture was carried out. The hill being heavily quarried today for granite is Choudammagudda. Sannarachammagudda can be seen beyond it. The modern village of Sanganakallu is visible in the upper left, while the town of Bellary can be seen in the middle distance. (Photograph by J.A. Soldevilla).

Figure 2: Map of the Sanganakallu-Kupgal archaeological complex. The grey shading indicates the location of the dolerite dykes on Hiregudda, which total four in number. The quarried dyke runs from Area $\mathrm{J}$ in the south-east to Area B in the north-west.

Figure 3: Thin-sections of the gabbro from the Northern dyke and dolerite from the Southern dyke (axe quarry) of Hiregudda (Photographs by David Gómez-Gras). A) general view of the intergranular texture of the gabbro rock containing crystals of augite (green) and plagioclase (light) under plane polarized light (PPL), and B) under crossed polars (PPX). C (PPL) and D (PPX) images of the microcrystalline intergranular texture in dolerite rock. E (PPL) and F (PPX) enhanced images showing augite crystals (red, blue and orange colours) occupying the spaces between plagioclase laths (grey).

Figure 4: Stages in axe production (not to scale): 1. natural dolerite block, 2. initial flaking of lateral edges of the block, 3. flaked blank, 4. blank with slight pecking traces, 5. blank with more intensive pecking, 6. polished axe; photography by José Antonio Soldevilla).

Figure 5: Relation between length and weight of axe blanks, finished axes and finished axes with signs of use-wear from Hiregudda (Area A and J) and Sannarachammagudda (Trench 10). Lines mark the relation between length and weight and are therefore indicative of higher (1/1) or lower (1/4) technical competence.

Figure 6: Polishing hollows from Choudammagudda at an initial, middle and final stage of development (Photograph by J.A. Soldevilla).

Figure 7: Circular structure (Feature 1) in Hiregudda - Area A (Photograph by P. Whittaker).

Figure 8: Relative proportion $(100 \%=1)$ of the main stone artefact categories in the three settlements of the Sanganakallu-Kupgal archaeological complex (axe blanks, hammerstones, polishing hollows are mainly related to axe production; handstones and grinding hollows are the main food-processing tools). These results are based on systematic surface recording of artefacts. Comparison with the material from test trenches shows a high correspondence between values.

Figure 9: Differences between Hiregudda (Area A) and Sannarachammagudda (Trench 10) in relation to the length and weight ratio of axe blanks. Lines mark the relation between length and weight and are therefore indicative of higher (left) or lower (right) technical competence. 
Figure 10: Partial view of the area with polishing grooves located in the plain below Sanarachammagudda and next to the modern village of Sanganakallu (Photograph by J.A. Soldevilla). 


\section{The Geographical, Geological and Archaeological}

\section{Context}

During the last five years, intensive research has been conducted in what appears to be one of the main prehistoric axe production centres of southern India (Boivin et al. 2005; 2007; Brumm et al. 2006; 2007; Fuller et al. 2007). The Sanganakallu-Kupgal archaeological complex, which includes several settlements, ashmounds, quarry sites and other activity areas, is located 6km east of the modern town of Bellary, in the centre of the Deccan plateau (Fig. 1). This region is characterised by semi-arid environmental conditions in the monsoon climatic belt, and such conditions were established by the third millennium BCE (Fuller and Korisettar 2004). The region came to the notice of Western scholars at the end of the 19th century owing to the occurrence of extreme famine under the Victorian occupation, which led to the starvation of 11 million persons (Davis 2001). The very dry region is at the heart of the earliest known Neolithic cultural sphere in peninsular India, where ceramics and ground stone tools are reported from as early as 3000 BCE (Korisettar et al. 2001a), and archaeobotanical evidence indicates cultivation of indigenous food plants alongside herding of introduced livestock during the third millennium BCE (Allchin 1963; Korisettar et al. 2001b; Fuller et al. 2004). The Neolithic culture in this area is characterised by distinctive ashmound sites, which feature thick accumulations of ash thought to derive from the burning of dung at seasonal cattle-penning sites, perhaps as part of ritual cycles (Allchin $\underline{1963}$; Korisettar et al. 2001a; Boivin 2004a; Johansen 2004).

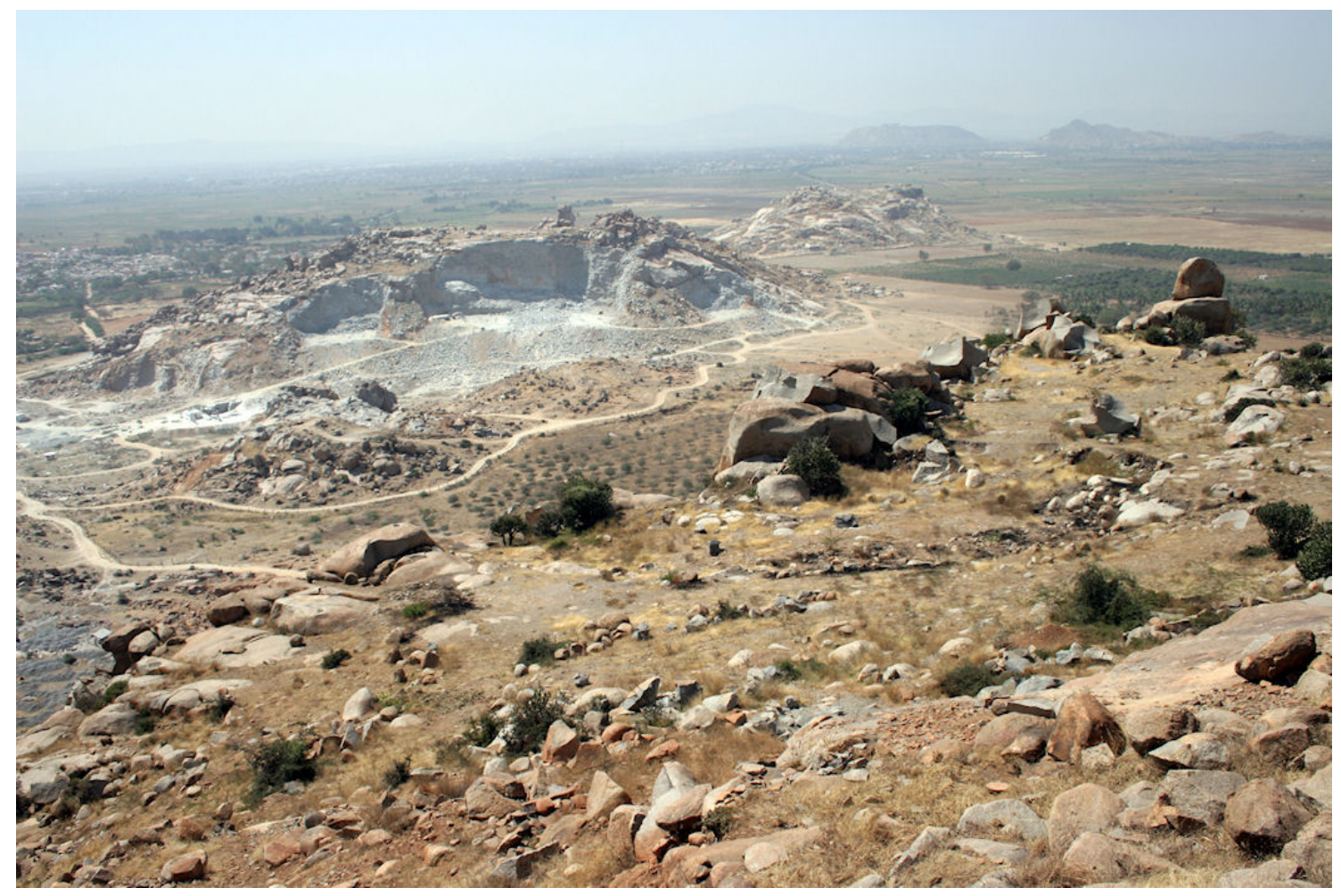

Figure 1: The three hills of the Sanganakallu-Kupgal complex. In the foreground is Hiregudda, taken from Area C, where quarrying of the upper reaches of the dolerite dyke was carried out, and looking down onto Area A, where stone tool manufacture was carried out. The hill being heavily quarried today for granite is Choudammagudda. 
The geological record in the Bellary district is mainly Pre-Cambrian in age and the rocks occurring can be divided broadly into three types: a) the gneisses and granites belonging to Peninsular Gneissic Complex (PGC), which are the oldest rocks and constitute the basement, b) the schistose rocks of Dharwarian age comprise both sedimentary and volcanic low-grade metamorphic rocks, and c) the younger Closepet Granite, which shows an intrusive relationship with both previous formations. In addition, different basic dykes of gabbro and dolerite rocks from Proterozoic age were probably emplaced following deep fractures in PGC and Closepet granite during the first steps of deformation, recorded in the shists as anticlines and synclines fold structures.

From a geological perspective, the Sanganakallu area is situated in the younger Archaean granitic formation (Dharwar batholith). The granitic bedrock emerges as inselbergs in the ancient floodplain. Frequent quartz and pegmatite veins and basic dykes of post-Archaean formation traverse these granites, mainly in a north-west/southeast to west-east direction. The size and composition of these dykes is highly variable. One of the dykes, which crosses part of the Hiregudda inselberg (the largest hill in the Sanganakallu-Kupgal complex), $1.5 \mathrm{~km}$ north-east of the modern village of Sanganakallu, was the focus of intensive prehistoric quarrying and axe blank production. The dolerite outcrop is about $700 \mathrm{~m}$ long and varies between approximately 10 -30m wide. Masses of manufacturing debris cover its surface over at least $500 \mathrm{~m}$ of its course, practically from the plain at the south-eastern foot of Hiregudda (450m asl), continuing in a north-west direction uphill to a height of $560 \mathrm{~m}$ asl. Three other dykes also traverse Hiregudda, but do not appear to have been quarried (see Fig. 2). 


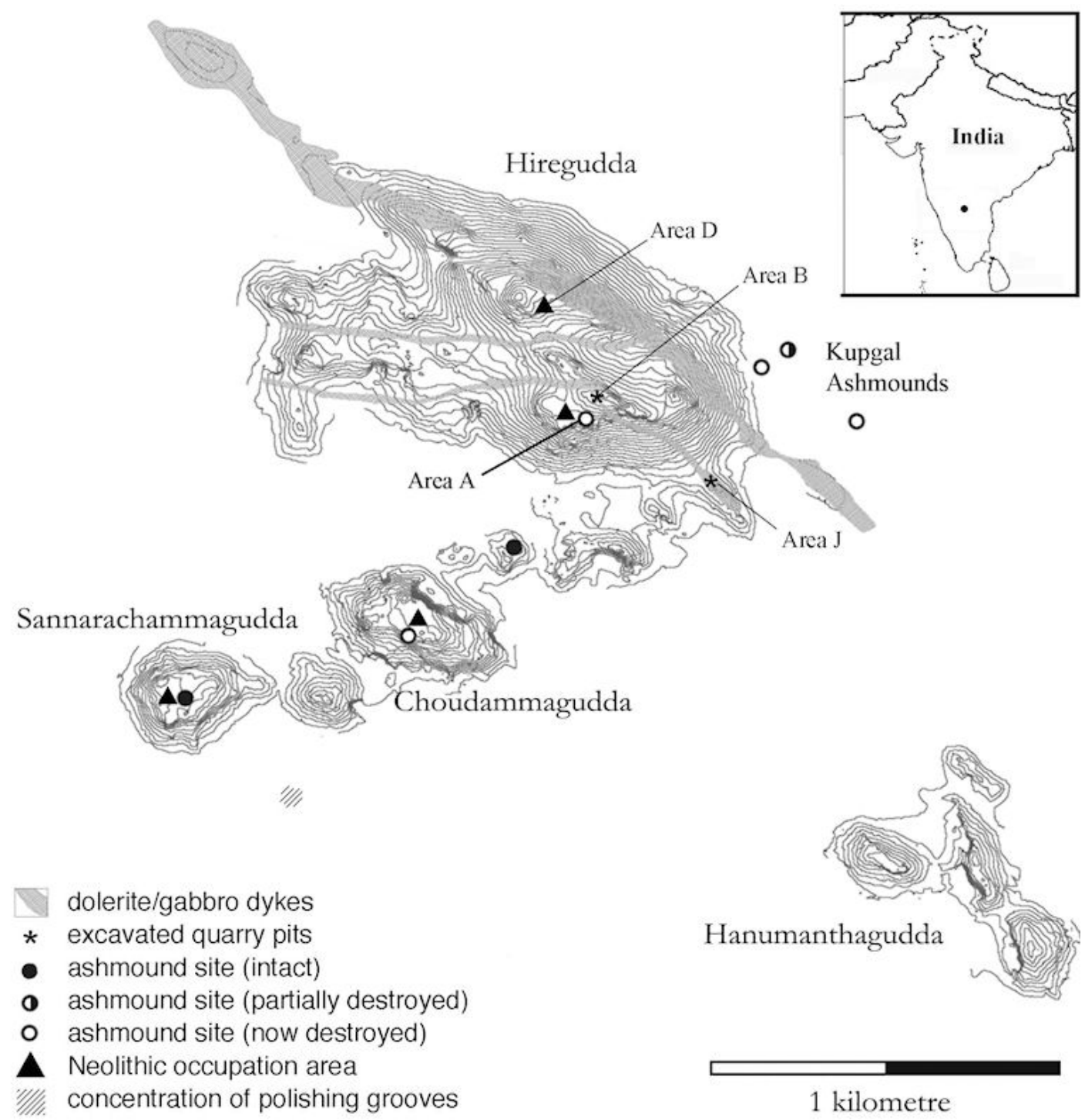

Figure 2: Map of the Sanganakallu-Kupgal archaeological complex. The grey shading indicates the location of the dolerite dykes on Hiregudda, which total four in number. The quarried dyke runs from Area $\mathrm{J}$ in the south-east to Area B in the north-west

The first notice of the exceptional quarry area at Hiregudda dates back to the observations of the British geologist, Robert Bruce Foote, at the end of the 19th century (Foote 1887; 1916), with subsequent explorations in the mid-20th century (Subbarao 1948; see Korisettar et al. 2001a). Foote referred to it as 'the most important neolithic settlement in the country' and 'the site of the largest neolithic manufacturing industry as yet met with in any part of India' $(\underline{1916}, 82)$. Recent work continues to illustrate its importance. Nonetheless, little research was carried out at Hiregudda subsequent to Foote's explorations, in part because the neighbouring site of Sannarachammagudda became a focus of investigation (Ansari and Rao 1969; Subbarao 1947; 1948). Renewed work was thus initiated at the site in 1997. Test excavations and sampling aimed at chronological placement and reconstructing subsistence were carried out in 1998 in Hiregudda Area A (Korisettar et al. 2001b; Fuller et al. 2004). Larger scale systematic excavation and mapping was carried out between 2003 and 2006, when several trial trenches were excavated in the upper and the lower parts of the dyke, named Hiregudda Area B and Area J respectively (Boivin et al. 2005). More than 95\% of the material 
recovered from the resultant trenches consisted of dolerite shatter and waste flakes. Axe blanks, hammer stones and a few horn tools also provide information about the activities carried at these quarries, as discussed below.

Close to the quarry, on the natural terraces extending across the top of Hiregudda, at least three settlement areas of $c$. 0.5-1 ha size and one ashmound were located. Excavations carried out in two of these areas (Areas A and D), one of which included the ashmound, confirm that these habitation and activity areas were, to a large extent, contemporary with the quarry (Boivin et al. 2005; Fuller et al. 2007).

Two additional settlements greater than 1 ha in size were identified on the granitic hills called Choudammagudda and Sannarachammagudda, located $700 \mathrm{~m}$ and $1400 \mathrm{~m}$ southwest of the quarry, and also form part of the Sanganakallu-Kupgal complex. While the first has only been investigated as part of one recent field season, Sannarachammagudda and its ashmound have been the target of archaeological research since the 1940s and represent one of the key stratigraphies for the later prehistory of southern India (Subbarrao 1948; Ansari and Nagaraja 1969; Korisettar et al. 2001b; Fuller et al. 2007). On both sites, the presence of axe blanks, dolerite debitage and different percussion and polishing tools leave little doubt that the inhabitants of both settlements were involved in axe production.

At this point in time, no radiocarbon ages are available for the quarry areas, but the dating programme carried out at the habitation sites of Hiregudda and Sannarachammagudda provide ages that indicate Neolithic occupation beginning at around $1950 \mathrm{cal}$ BCE (Fuller et al. 2007). Although axe manufacture formed part of the local economy from the beginning, the intensity of production underwent important variations over the centuries. After c. 1100/1000 cal BCE the settlements were apparently abandoned, and evidence from later occupations is scarce. The excellent preservation of the archaeological record, and the quantity and variety of means of production present on the settlement and quarry areas makes the Sanganakallu archaeological complex attractive for the study of social and economic organisation and prehistoric axe production. 


\section{The Petrographic Composition of the Hiregudda Sanganakallu Dolerite Dyke}

One of the main questions that arises in view of the scale of quarrying and axe production at Hiregudda concerns the material properties of the dolerite dyke targeted by prehistoric peoples. As already mentioned, this type of basic dyke is a common geological feature of southern India, but at the Hiregudda locality, evidence of largescale prehistoric exploitation is especially notable. It appears to have been a particular focus of axe production activity. While petrographic characterisation is necessary in order to define the distribution network of the Sanganakallu artefacts, it is possible that they were exchanged or traded over large parts of southern and central India.

Field survey enabled us to observe that marked differences exist between the quarried dolerite outcrop at Hiregudda and another dyke just 180-200m further north that also traverses the hill. This latter much wider and larger outcrop, which runs parallel to the quarried dyke, and extends along the top of Hiregudda, was a local focus of petroglyph creation (Boivin 2004b; Fawcett 1892). One can imagine that the dark colour of this chain, formed by large boulders running through a light granite hill, was perceived to be of particular symbolic importance. The rock can best be defined as a coarse-grained, extremely hard gabbro. It was used as raw material for percussion and abrasive tools on all three hill settlements, as well as in the quarry. 

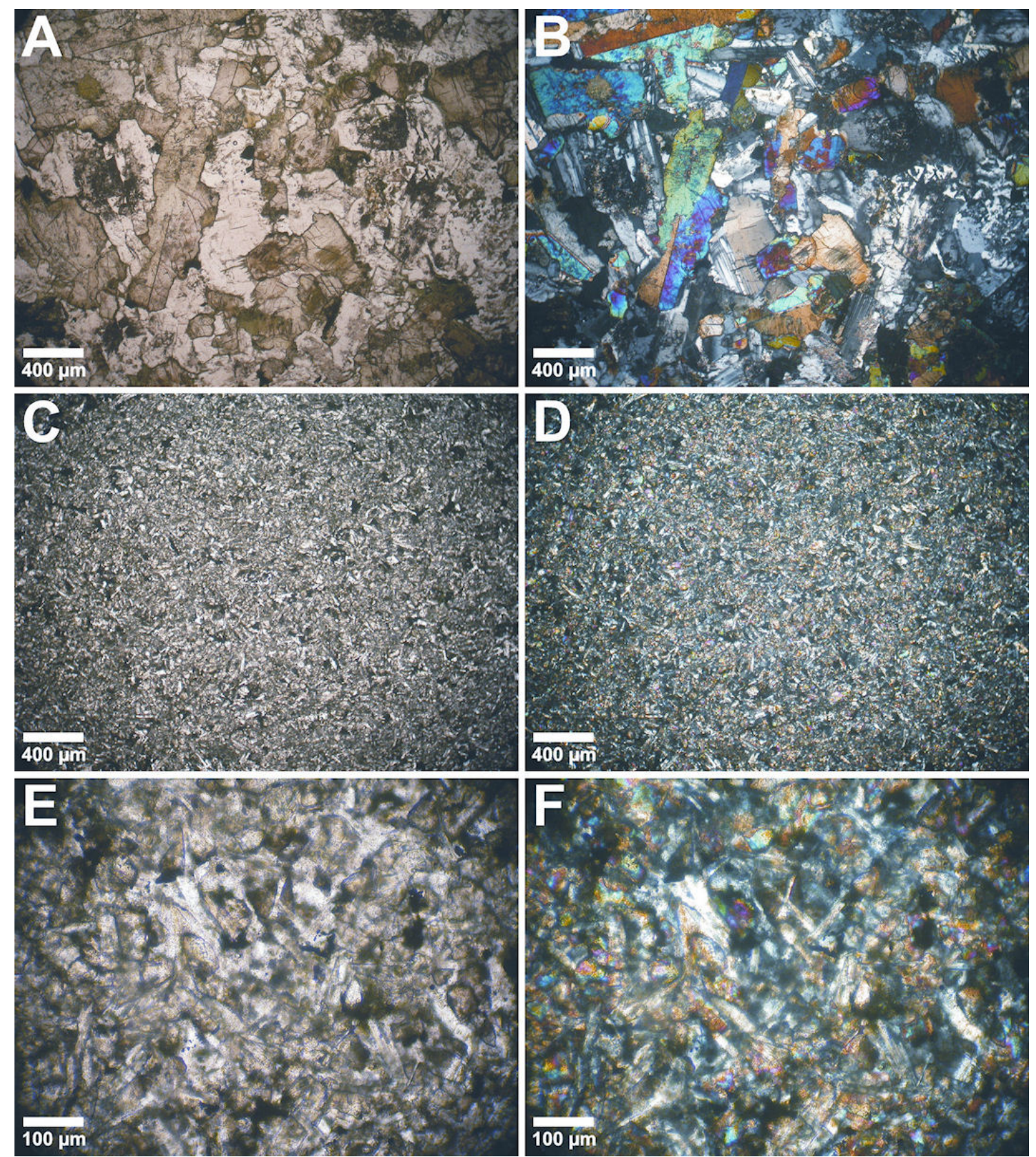

Figure 3: Thin-sections of the gabbro from the northern dyke and dolerite from the southern dyke (axe quarry) of Hiregudda (Photographs by David Gómez-Gras). A) general view of the intergranular texture of the gabbro rock containing crystals of augite (green) and plagioclase (light) under plane polarized light (PPL), and B) under crossed polars (PPX). C (PPL) and D (PPX) images of the microcrystalline intergranular texture in dolerite rock. E (PPL) and F (PPX) enhanced images showing augite crystals (red, blue and orange colours) occupying the spaces between plagioclase laths (grey)

Rock samples were taken from both dykes as well as from archaeological materials and submitted for petrographic analysis through thin-sectioning (Fig. 3). The two identified rock types can be characterised as follows:

- The dolerite is a microcrystalline gabbro showing an intergranular texture formed by augite crystals occupying the spaces between plagioclase laths.

- The gabbro consists of a fine- to medium-grained holocrystalline rock with intergranular texture. The rock mainly contains crystals of plagioclase, augite 
The textural arrangement of the crystals forms a 3-D holocrystalline isotropic framework in both rocks and confers high mechanical strength. Moreover, the microcrystalline grain size of the dolerite allows a conchoidal fracture, one of the necessary conditions for flaked axe production.

Experimental tests were carried out in order to gain a better understanding of the material properties of the rock and its behaviour during the knapping, pecking and polishing stages, as these represent the documented techniques used in Hiregudda axe production. Flaking of natural blocks and slabs confirmed the conchoidal fracture habit of the material when submitted to heavy impacts. Pecking and polishing tests proved the extreme hardness of the dolerite. It is worth mentioning here that part of the experiments were carried out by local male villagers, whose usual income derives from manual quarrying of the granite and who are familiar with the mechanical properties and working of stone. Axe blanks collected from areas disturbed by modern quarrying were ground on granite bedrock with the addition of water and sand, which had previously been prepared by crushing the same granite. Without the addition of this abrasive material, the grinding process proved practically impossible and required considerably more strength. Every 30 minutes, the axe blank was cleaned, documented and weighed. Soon it became evident that most grinding efforts had to be carried out on the thickest part below the edge, confirming the importance of a previous competent flaking strategy. The mean material loss, or abrasion wear index, was hardly $3 g$ of dolerite an hour. The grinding of afanitic rocks from the axe factory of Plancher-lesMines (Vosges) on sandstone slabs resulted in wear indices between 5-13g/hour (Petrequin and Jeunesse 1995, 41). Given the hardness of the Sanganakallu dolerite, the grinding of a reasonably well-prepared blank into a usable edged tool of $90-100 \mathrm{~mm}$ length would probably have required around 6 hours of work. Much more effort would be necessary in order to obtain a completely polished axe. 


\section{Technical Organisation of Production}

The excavation and surface surveying of the quarry area and the three hill settlements have provided abundant information on the axe production process and its organisation. The test trenches placed in the upper and lower parts of the dolerite outcrop show that the quarrying took advantage of the intense fracturation of the deposit by systematic joints. This enabled the extraction of small blocks or slabs with relatively little effort, and clearly represents an important economic advantage in comparison to the other dykes. (Foote (1916, 82), a geologist who travelled widely through southern India, mentions that the occurrence of such weathering dolerite outcrops was a very unusual phenomenon for the trap-dykes that occur in such great numbers on the Deccan plateau.) Percussion stones of dolerite, gabbro and granite, as well as chisels of antelope horn, found within the quarry debris, were used to break up the deposit. A spherical hammerstone, weighing $1767 \mathrm{~g}$, made out of gabbro from the northern dyke, is the heaviest artefact of this type recorded so far at Sanganakallu. The main operation involved obtaining $150-300 \mathrm{~mm}$ long blocks, slabs or nodules of angular, sub-angular or sub-rounded shape. Their outer surface has a yellow-orange colour, resulting from oxidation of the rock minerals by weathering processes in the systematic joints. This surface alteration has proved to be a helpful trait in reconstructing how the natural slabs were worked. Traces of this 'skin' remains, to a larger or smaller extent, on $c .50 \%$ of the unfinished products as well as on some used axes. In $8 \%$ of the blanks, surface alteration appears on the dorsal as well as ventral sides of the blank, indicating the thinness of some of the selected slabs.

In general, three reduction strategies have been identified in the Sanganakallu lithic assemblage. The methods are defined mostly on the basis of the initial dolerite stone packages utilised (Brumm et al. 2007). These include:

1. large symmetrical sub-rectangular stone blocks and thick slabs;

2. thin flat cortical slabs;

3. flake blanks and non-flake debitage of varying shapes and sizes.

In all cases, the dominant procedure was to work the blocks, slabs or flakes bifacially around the perimeter of the stone piece (Fig. 4). Yet, considerable variation in the knapping procedures can be observed within all three strategies, suggesting that persons with very different skills and habits were operating simultaneously in the area (Brumm et al. 2007). 

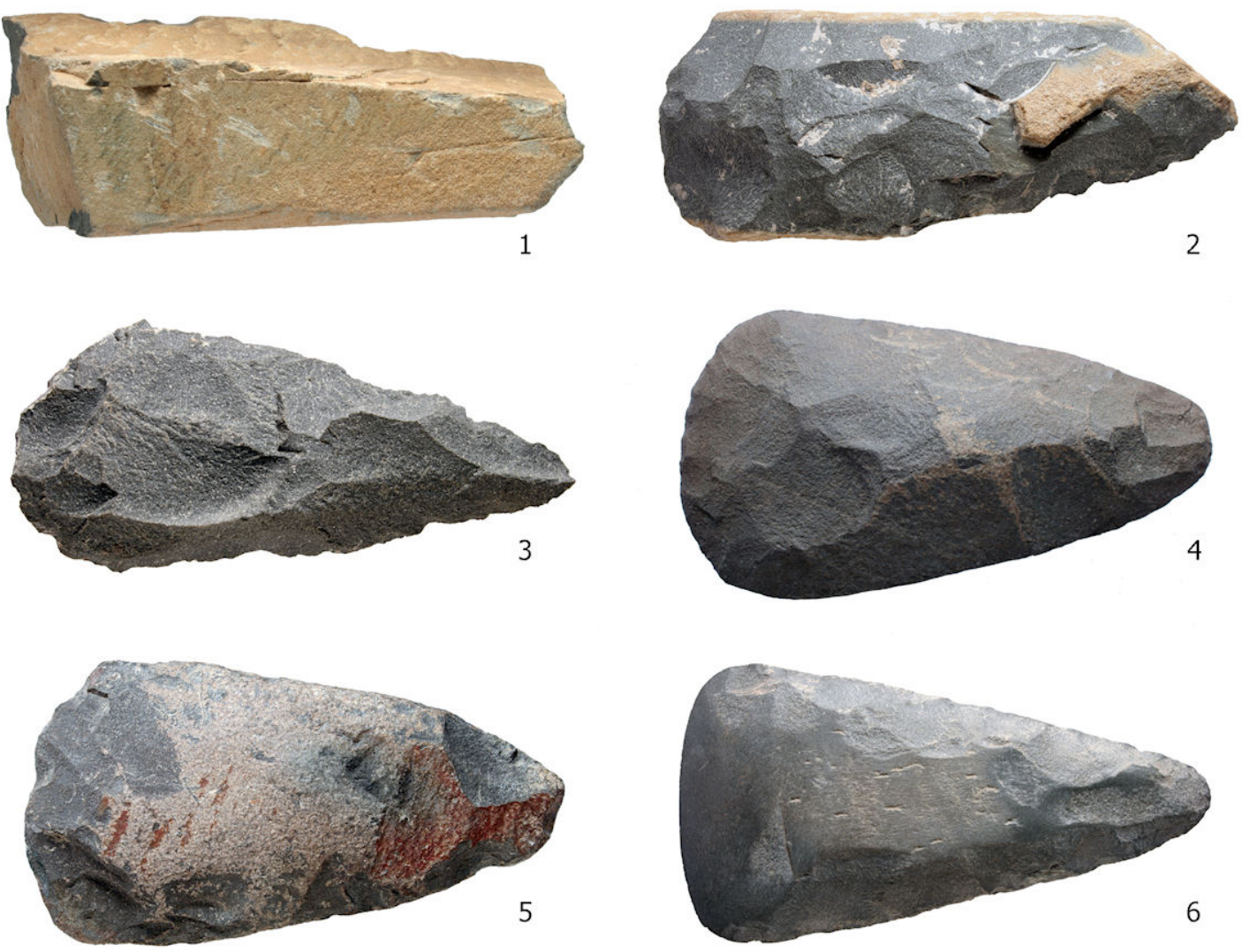

Figure 4: Stages in axe production: 1. natural dolerite block, 2. initial flaking of lateral edges of the block, 3. flaked blank, 4. blank with slight pecking traces, 5. blank with more intensive pecking, 6. polished axe (note different scales; photography by José Antonio Soldevilla).

The main target that needs to be achieved in the knapping process is the reduction in thickness of the rough-outs, as thinner axe blanks will require less pecking and grinding. Unskilful knapping is visible in the form of thick blanks with no further modification. These resulted in discard in the quarry and settlement areas. On occasion these thick blanks were transformed into percussion tools. It is much easier and quicker to dress thin slabs or flakes (methods 2 and 3) than to work larger blocks and slabs, which requires a higher level of technical control (method 1) (Brumm et al. 2007). In this case, the rocks were reduced on one face through lateral flaking, while knapping on the opposite face was much less invasive, thus taking advantage of at least one of the flat surfaces of the slabs or blocks. Again, the underlying principle seems to be to spare effort and time during the knapping, as well as during the later pecking and grinding stages.

One possible way of determining the technical competence or variation of knapping is to consider the relation between the length and the weight of the blanks and finished axes. High technical control results in thin artefacts, which require shorter polishing processes and/or provide sharper edges. Depending on the type of natural rocks used, it also enables the maximisation of raw materials. Low flaking skills produce thick and, consequently, heavier artefacts. Therefore, the relation between length and weight provides a useful analytical test to evaluate the degree of skill manifest in the flaking process. (This agrees with observations made by Stout (2002) among the Langda adze 
makers of Irian Jaya. The more skilled knappers produce longer but not wider or thicker blanks. Consequently, high technical competence results in proportionally lighter artefacts.) If we correlate these two variables measured on a sample of artefacts from the Sanganakallu axe collection, it can be observed that variation in production is high (Fig. 5). On average, unskilled examples are 2.8 times heavier than the well-flaked blanks of the same size. For example, the weight of a typical $100 \mathrm{~mm}$ long axe varies between 100 and $240 \mathrm{~g}$. As expected, most of the finished and used axes fall among the lighter examples. It seems reasonable to assume that many of the artefacts found during survey and excavation were in fact discarded because of the low-quality knapping and the workload that finishing them would have created. The technical organisation of production was not very rigid, and persons with different levels of skill seem to have been at work simultaneously.

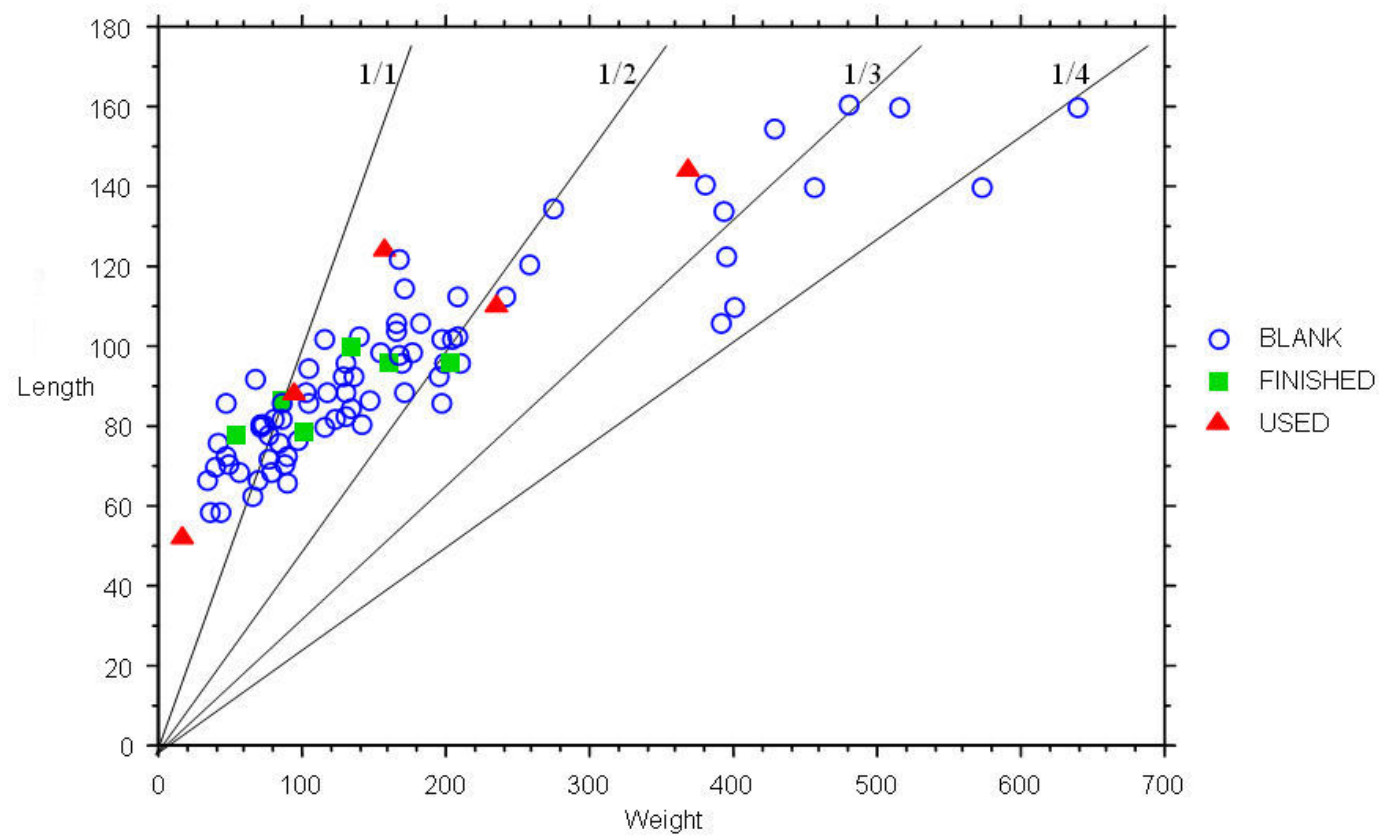

Figure 5: Relation between length and weight of axe blanks, finished axes and finished axes with signs of use-wear from Hiregudda (Areas A and J) and Sannarachammagudda (Trench 10). Lines mark the relation between length and weight and are therefore indicative of higher $(1 / 1)$ or lower $(1 / 4)$ technical competence

About 25-30\% of a test sample of finished axes and blanks from Hiregudda and Sannarachammagudda showed traces of pecking, visible as small pits (Fig. 4). This process seems to have been carried out with the same type of dolerite, gabbro, quartz and granite percussion stones as flaking, and mainly served to reduce the highest points and crests of the preforms. The pecking traces rarely cover more than $20 \%$ of the surfaces. It appears that this working stage was only applied occasionally, in order to reduce irregularities or blank thickness resulting from knapping errors.

The final stage of stone axe production consists of grinding and, eventually, polishing. As in the case of pecking, this labour-intensive process rarely affects the whole surface of the artefact, leaving traces of earlier work stages and even parts of the surface skin of the raw material (see also Allchin 1957). In many cases only the cutting edge is polished. Again, the technical organisation of the production process seems to have been guided by utilitarian and quantitative criteria, rather than by the finishing and aesthetic aspect of the products. As indicated below, it is possible that a considerable portion of the blanks or preforms were not ground in the Sanganakallu area, but in 
settlements further away. It is likely that only some of the artefacts were polished locally (see also Boivin et al. $\underline{2005}, 77$ ).

One of the longest known archaeological features of the three hill-settlements are the grinding or polishing grooves and hollows found in the granitic bedrock or across much of the surface of large boulders (Subbarao 1948; Boivin et al. 2007). Use-wear analysis, as developed for the study of macro-lithic artefacts (Adams 2002; Risch 2002), has been carried out on the working surfaces of these features, in order to confirm their participation in the axe-grinding process. This is the first such analysis of the features, and indeed of any grinding hollows in India. The mesoscopic observation (5-20X) of the working surfaces has shown that not all of these features served the same purpose and that many were used for different tasks. Mainly the smaller and oval hollows or 'slicks' present evidence of intensive abrasion and use-wear traces related to the grinding of stone (Fig. 6). The larger rounded hollows, in contrast, show traces related preferentially to grain processing. Experimental tests confirmed that the deeper oval features allow a nearly mechanical grinding of the blank's edges by placing the whole artefact in the hollow, pressing it with the flat hand and carrying out a rocking movement with it. Such an operation is much more comfortable than holding the blank in the hand and grinding only the frontal cutting edge against the rock surface. In fact, many artefacts show polishing traces around the periphery, especially on the bevelled edge and the opposite butt, while the flat surfaces of the dorsal and ventral faces remain largely unchanged because of a lack of contact with the convex grinding hollows.

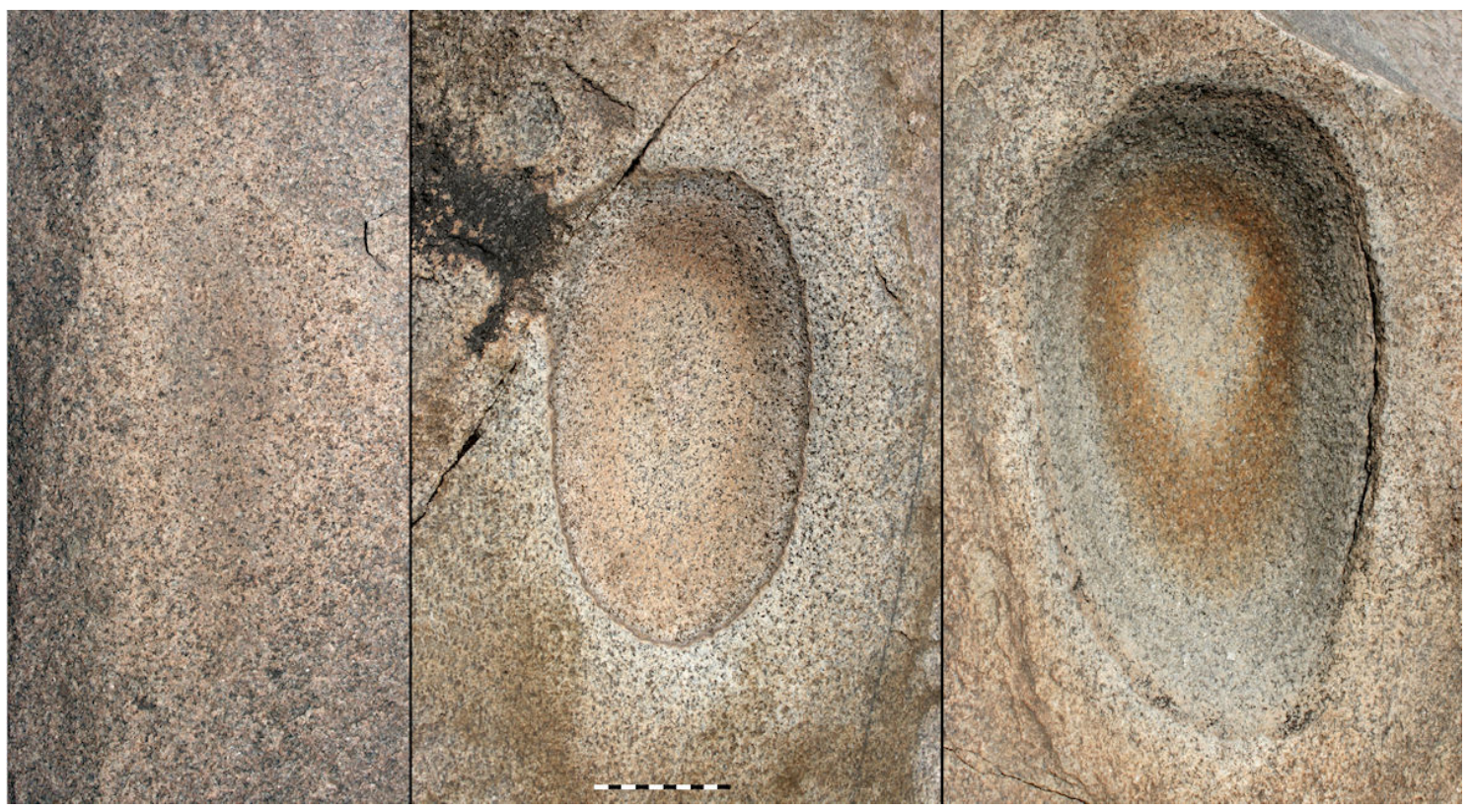

Figure 6: Polishing hollows from Choudammagudda at an initial, middle and final stage of development (Photograph by J.A. Soldevilla)

A different form of grinding must have been carried out in the $\mathrm{V}$-shaped polishing grooves, which are much less frequent in the settlements. Such features are known from ethnographic and experimental examples and allow the polishing of lateral edges (e.g. Kennedy 1962; Delage 2004, 40). In addition to the highly levelled grain surfaces, the intensity of the activity carried out in these grooves and the hardness of the worked material is also revealed by scratches and deep striations on the groove surfaces. 


\section{Socio-economic Organisation}

The excavation and survey campaigns carried out between 1997 and 2006 on all three settled inselbergs around the dolerite quarry have provided information about the social and economic organisation of axe production in the Sanganakallu area. Though the archaeological record of the area is still undergoing study, these findings offer some insights into the social relations of production in the second millennium BCE. One of the central issues concerns the social access to critical natural resources and the organisation of the different production stages among the population, as well as the possible emergence of relations of social and political dependency.

The lithic material recovered along the dolerite outcrop corresponds to the quarrying activity itself, as well as to a massive amount of flaking of bifacial axe blanks. Large amounts of reduction flakes and discarded axe blanks cover the south-eastern slope of Hiregudda. As one moves up the dyke, other stone artefacts, such as handstones, or mano, and grinding slabs for cereal processing, as well as pottery, begin to appear. This shows that the dolerite outcrop lay close to settlement areas expanding on the hill of Hiregudda, and seems to have overlapped with them. Hence, quarrying activity was not taking place in a separated and exclusive territory, as was the case at Great Langdale or other European extraction sites (Bradley and Edmonds 1993; Petrequin and Jeunesse 1995; Le Roux 2002; Petrequin et al. 2006), but rather formed part of a more or less loosely settled territory. It still needs to be clarified if the occupation next to the quarry was a permanent form of settlement, or rather some form of temporary, seasonal arrangement. In any case, the central and south-eastern part of the Hiregudda plateau, 80-120m away from the dyke, shows evidence of a rather stable form of occupation.

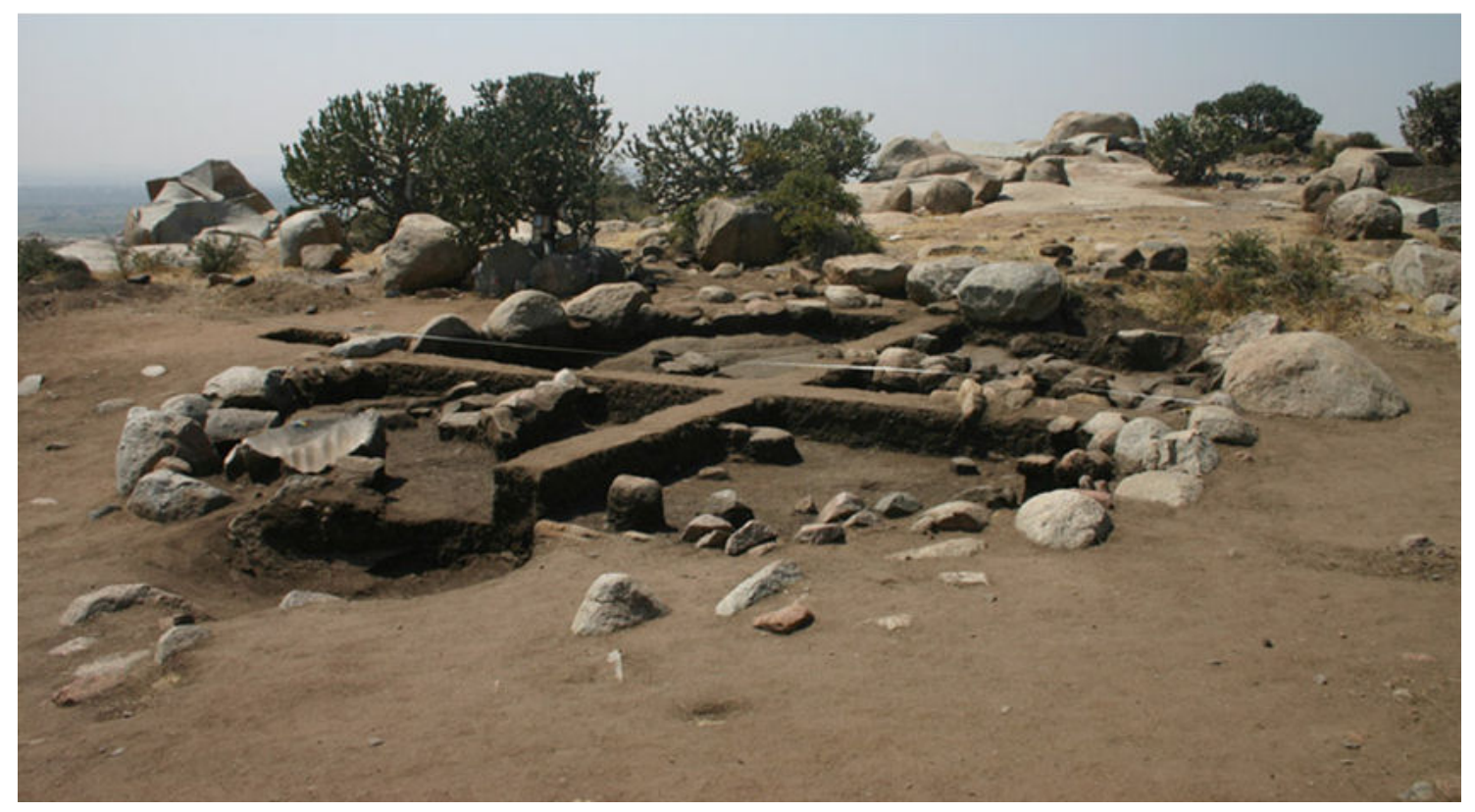

Figure 7: Circular structure (Feature 1) in Hiregudda - Area A (Photograph by P. Whittaker)

Intensive survey and excavations have been carried out at the upper end of the dolerite dyke, in Area A of Hiregudda. In addition to containing a partly destroyed ashmound, this site presents the most outstanding accumulations of dolerite debitage waste of any 
of the Sanganakallu settlements. Of particular interest is a round structure, $7 \mathrm{~m}$ in diameter and visible on the surface, named Feature 1, which was fully excavated (Fig. 7). The use of this structure dates between 1700 and 1250 cal BCE, with a possible hiatus between 1500-1400 BCE (Fuller et al. 2007). While stone artefact production debris is found throughout the structure's sequence, the lithic-rich upper deposits inside and around this building, containing hundreds of thousands of flakes from axe manufacturing, accumulated to a large extent between $c$. 1500/1400 and $1250 \mathrm{cal}$ BCE. The volume and type of flakes strongly supports the idea that this stone-lined circular structure functioned as a specialised lithic production 'workshop' for the manufacture of axes and other dolerite implements, such as chisels. The long, narrow and more or less cylindrical preform of these latter artefacts requires a particularly skilful knapping technique, which seems to have been exclusive to Area A and particularly to Feature 1.

While the manufacture of dolerite axes was the dominant activity over at least the last 150 years Feature 1 was occupied, it is equally clear that other activities also took place within this building. Apart from dozens of dolerite, gabbro, quartz and hematite hammerstones and a large stone slab with polishing grooves linked to axe production, the structure's users disposed of cereal processing tools (handstones and querns), polishing artefacts and even one pottery burnisher. Finished axes and chisels suggest that wood-working could have been carried out as well. Repairing and resharpening of edge tools also took place, as can be inferred from the presence of flake and non-flake debitage bearing ground facets as well as some reworked axes (Brumm et al. 2007).

The spatial distribution of the artefacts and debris within Feature 1 shows a clear pattern, and the structure appears to have been entered from the south. According to the distribution of debitage waste, axe production seems to have been 3.3 times more intense in the western than in the eastern half of the room. A large immobile granite quern placed in the south-east corner seems to have been transformed during the final occupation into an axe-grinding artefact, which may indicate the greater importance of axe production activities during the last centuries of the occupation. Pottery and ashes are more frequent in the north-eastern corner, suggesting that this was an area for food preparation and consumption. Outside the dwelling, large amounts of knapping debris accumulated and seem to have resulted from periodic cleaning of its inner space. The presence of 16 grinding grooves on granite boulders recorded in Hiregudda, absent or rare on the other hill settlements, confirms that the specialised edge grinding and finishing of axes and chisels represented another important and time-consuming activity in Area A. Clearly, the inhabitants of other more 'domestic' structures and dwellings identified in the vicinity were participating in these tasks and maintained a close relation with the production processes taking place in Feature 1. The analysis of the knapping debitage as well as of the discarded axe blanks has confirmed that a variety of working methods were carried out inside and outside Feature 1 by persons showing very different levels of technical competence. This pattern does not conform to a highly specialised workshop, nor to domestic production with a specialised working tradition passed from generation to generation. While a typical example of the first is the modern production of beads in Khambat, Western India (Kenoyer et al. 1991), the domestic type of specialisation would include the blade production proposed for the Magdalenian of the Paris basin (Pigeot 1987); for a general discussion on the meaning of technical specialisation, see Risch 2008). Rather, the combination of technically diverse, and at the same time more and more intense knapping during the last 150-250 years of the occupation of the site, suggests collective production carried out by a team of part-time 
knappers and polishers, whose target was mass production rather than the development of a high degree of technical expertise. The lack of concern with raw material maximisation indicates that good dolerite stone was abundant and easily accessible.

Access to the dolerite stone was not exclusive to the inhabitants of Hiregudda. The lithic records of Choudammagudda and Sannarachammagudda show that these settlements obtained natural slabs or blocks as well as half-finished blanks from the same dyke (Fig. 8). Percussion tools as well as dolerite debitage confirm that their populations were producing or finishing axe blanks. Differences in the organisation of axe production between communities emerge in the intensity of finds rather than in the organisation of activities. Thus, while discarded axe blanks represent around $30 \%$ of the macro-lithic tools recorded at Hiregudda Area A, their importance drops to around $10-15 \%$ at the other sites (Fig. 8).

The results obtained from the other settlements do not show a superior or inferior degree of technical competence among their knappers. Discarded blanks from Choudammagudda and Sannarachamma show the same type of working procedures and mistakes in comparison to the areas close to the quarry, although axe production was clearly a less important activity. Handstones, a clear indicator of the processing of cereal and other crops, represent more than $30 \%$ of the macro-lithic tools recorded through systematic surface survey in these two settlements. In Hiregudda they only represent around $24 \%$ of the macro-lithic assemblage. The frequency of surface grinding slabs and hollows is much larger at Choudammagudda and Sannarachamma than at Hiregudda, also suggesting differences in the activities conducted in the settlements (Fig. 8).

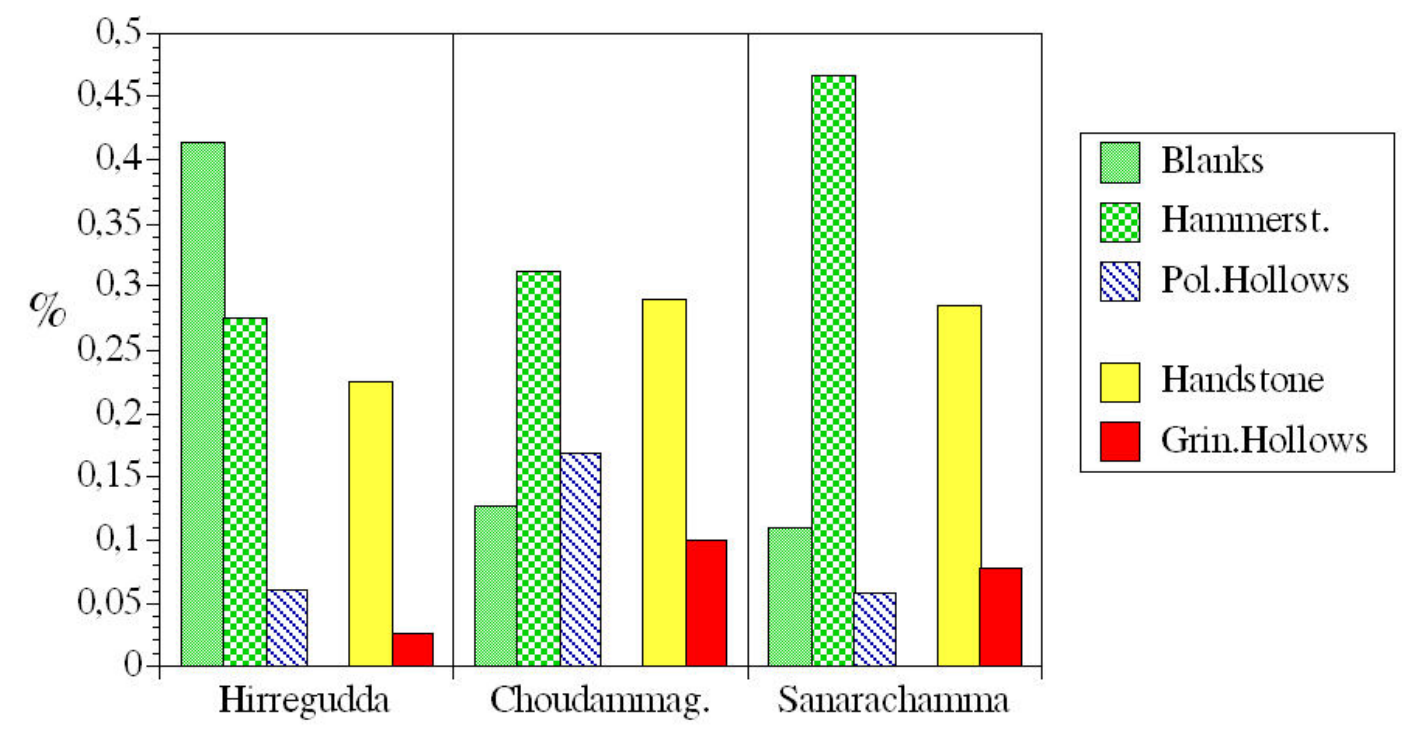

Figure 8: Relative proportion $(100 \%=1)$ of the main stone artefact categories in the three settlements of the Sanganakallu-Kupgal archaeological complex (axe blanks, hammerstones, polishing hollows are mainly related to axe production; handstones and grinding hollows are the main food-processing tools). These results are based on systematic surface recording of artefacts. Comparison with the material from test trenches shows a high correspondence between values.

The hill settlement of Choudammagudda, located $700 \mathrm{~m}$ south-west of the dolerite quarry, is characterised by a significantly high number of surface axe-grinding hollows. Given its size, it may have been occupied by the largest community of the Sankanakallu 
area (although the limited excavations so far suggest that deposits may not be as deep as at the other sites) and it is possible that it could therefore have devoted more work-force time to axe polishing. The large number of handstones, grinding slabs and grinding hollows recorded on the surface suggests the permanent character of this settlement and the importance of the processing and consumption of agricultural products within it.

The southernmost settlement of the Sanganakallu-Kupgal complex, at Sannarachammagudda, has a surprisingly high proportion of percussion stones, particularly of dolerite and gabbro, confirmed both through surface survey and excavation (Trench 10). The presence of dolerite blocks, flakes and blanks on the site confirms that this community obtained useful raw materials from the Hiregudda quarry and participated in axe production. According to the length/weight index of axe blanks used to describe technical competence, the knapping skills at Sannarachamma were not lower than those displayed at Hiregudda (Fig. 9). Other aspects of the knapping process show that all three sites shared the same technology and expertise. However, the high proportion of hammerstones at the southern hill site can also be related to the knapping of other materials, including the production of small flake and bladelet tools on quartz and chert, as well as to the preparation and maintenance of cereal-grinding tools, which have here a similar importance to that observed at Choudammagudda (Fig. 8). Finally, the low number of grinding hollows and grooves at Sannarachamma indicate that a limited work-force was involved in axe grinding at this site.

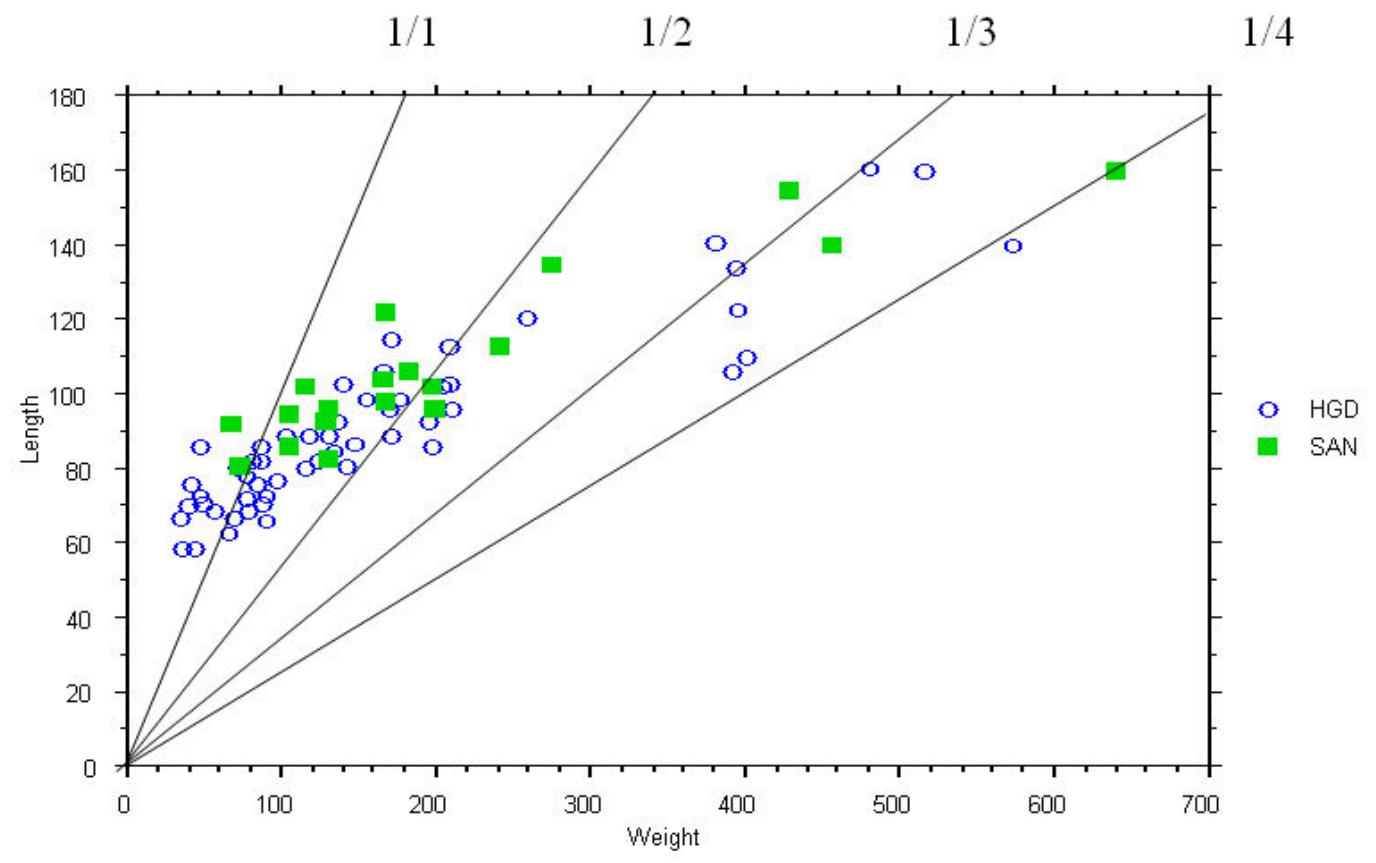

Figure 9: Differences between Hiregudda (Area A) and Sannarachammagudda (Trench 10) in relation to the length and weight ratio of axe blanks. Lines mark the relation between length and weight and are therefore indicative of higher (left) or lower (right) technical competence.

In general, it can be concluded that the same set of stone tools and raw materials were produced, maintained and used on all three hills. All settlements had direct access to the dolerite quarry or, at least, to the products produced there, as the presence of unworked blocks and blanks suggest. Economic differences existed among the settlements as demonstrated by different work efforts and the different activities performed at the settlements. While Hiregudda, and particularly Area A, centred on the quarrying and 
working of dolerite, the other settlements appear to have been more agriculturally oriented. The transactions between the settlements seem to have been fluid, given the exchange of materials and technologies between them. One might even ask if Area A, at least during the final occupation phase, was more of a working area used periodically by groups coming from the other settlements, rather than a settlement itself. In any case, the presence of a considerable quantity of crop-grinding hollows, as well as the evidence from Feature 1 itself, suggests that everyday subsistence activities were not an unusual activity in the area.

The distribution and organisation of the means of production in the Sanganakallu area indicates a considerable circulation in terms of populations, raw materials, axe blanks, technological skills and, typically, subsistence goods between the three hill settlements. The division of tasks within this society seems to have been limited, and in general all communities living in this area were engaged to a certain extent in the flaking, pecking and grinding of dolerite axes. However, the production of chisels appears to have been restricted to one area close to the dolerite outcrop. So far, the study of the lithic means of production does not suggest any marked division of labour between settlements nor in the excavated house units. Neither can signs of economic centralisation be identified in the area. Yet, the scale of axe production leaves no doubt that we are not dealing in any of the three hill-settlements with a self-sufficient communal production. No approximate calculation of the total volume of axes produced in the Sanganakallu area has been carried out so far, but the figure definitely lies in the many thousands, rather than the hundreds. The manufacture of such quantities of utilitarian objects only makes sense if an extra-regional distribution system existed. 


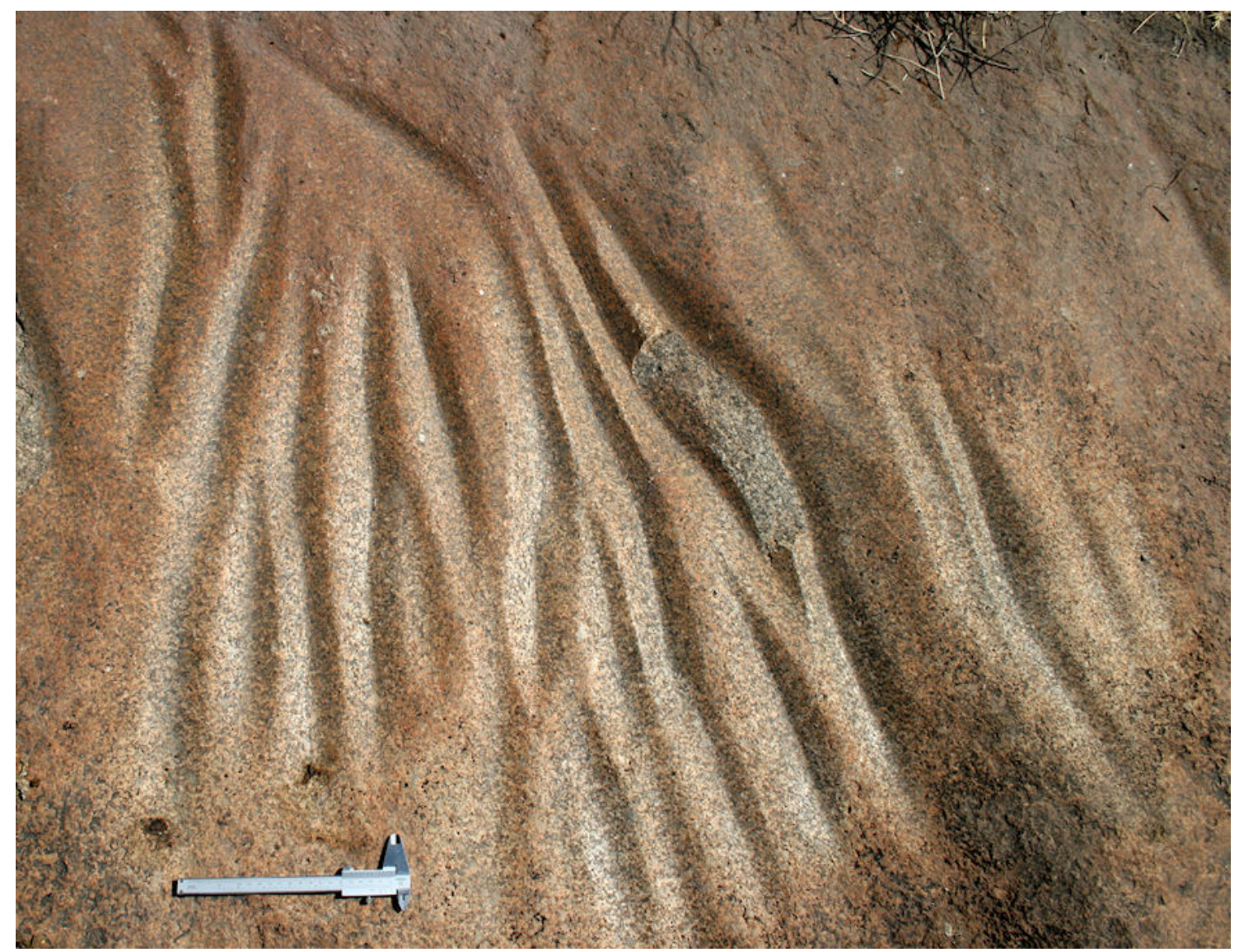

Figure 10: Partial view of the area with polishing grooves located in the plain below Sanarachammagudda and next to the modern village of Sanganakallu (Photograph by J.A. Soldevilla)

In this socio-economic context, it is of interest that the most highly specialised activity area discovered so far lies separated from all settlement areas, c. $400 \mathrm{~m}$ south-east of Sannarachamma. On several more or less flat granite bedrock surfaces across an area of c. $30 \times 25 \mathrm{~m}$, we have recorded up to 138 grinding grooves (for previous discussion of these grinding grooves, see Subbarao 1948; Brumm et al. 2007, 73.). Probably their original number was much higher, given erosion processes and destruction caused due to their position next to the modern village of Sanganakallu. All grooves show the characteristic ' $\mathrm{V}$ ' section already observed around Feature 1 of Hiregudda, although many are much larger, reaching up to $1 \mathrm{~m}$ in length (Fig. 10). In fact, they are the result of a successive juxtaposition of several shorter grooves. Such grooves do not seem appropriate for the grinding or polishing of the axes, nor their cutting edges, which require wider, flat or 'U' shaped grooves, as known from African, Australian as well as European axe production areas (e.g. Shaw 1944; McCarthy 1976, 54). Rather, these grinding surfaces seem to result from polishing the lateral margins and the butt of the axes and, in consequence, they must be related to the finishing of axes or chisels.

Although the labour force responsible for the development of such grooves is considerable, as became manifest in the experimental tests, no settlement traces can be identified in the neighbourhood. Even if the modern village may have disturbed such deposits, surface finds should be expected. The clear spatial separation of this area must result from an intentional social or political decision, as no significant geological differences exist between this bedrock and the granite forming the surfaces of all three inselbergs. In fact, similar lateral grinding was carried out on a much more limited scale 
on Hiregudda Area A and occasionally also on Sannarachamagudda. Consequently, these specific axe-grinding activities and/or the persons carrying them out were maintained apart from the everyday habitation areas. Our impression is that other groups were present in this specialised area. Its position on the plain, south of the two largest habitation sites and away from and out of sight of the dolerite quarry would be an appropriate location at which to engage with communities of a wider region and carry out the exchange of either axe blanks or more or less finished products. Perhaps the finishing of the axe margins in such a context of negotiation might have been considered a proof of the value of the offered products. Alternatively, axe finishing may have been carried out by the visiting groups themselves, or by diverse communities during the course of social and exchange activities.

\section{Conclusions}

The Sanganakallu-Kupgal area represents a unique archaeological complex in South Asia. Given that there has been a reprieve in the present-day quarrying of the granite inselbergs, the archaeological sites of the area will continue to offer exceptional opportunities to investigate the social and economic organisation of prehistoric axe production strategies. The research carried out so far shows that at least three hill settlements, probably with a few hundred inhabitants each, were engaged in the quarrying and working of a special type of dolerite. Its easy extraction, fine-grained texture and extreme hardness made it a highly suitable raw material to manufacture chisels, adzes and axes through flaking, pecking and intense polishing. The access of all three settlements to raw material, and the similarity between them of working techniques and artefact types, indicates that the communities shared basic economic resources and were closely related. Accordingly, a marked division of tasks between the hill settlements did not develop. Apart from axe manufacture, all communities were engaged to some extent in other tasks, such as food processing, pottery-making, bead production, etc.

The botanical evidence from Sannarachama and Hirregudda Areas A and D also points towards similar agricultural practices amongst the hills and the broader regional culture, based primarily on the cultivation of two types of millet (Setaria verticillata, Brachiaria ramosa) and three pulses (Macrotyloma uniflorum, Vigna radiata, Lablab pupureus). The increase of wheat and barley in the final stages of occupation is detected in both settlements where botanical studies have been undertaken (Fuller et al. 2001; Fuller et al. 2004; Fuller 2006, 48-53). Evidence of associated weed seeds and limited chaff (and hulled millet grains) suggests that archaeobotanical data derives from routine dehusking and final winnowing activities, and that initial threshing and winnowing after harvest was carried out elsewhere and not on occupation sites (Fuller et al. 2004, 117). The presence of quernstones and some grinding hollows on the hills suggests the context for final processing on these hill sites (Fuller et al. 2001), although it is now clear that large, round and shallow food-processing features must be distinguished from the more narrow and deep features involved in axe production (a distinction not recognised in the earlier paper of Fuller et al. 2001). Faunal evidence indicates the predominance of domesticated cattle, sheep and goat meat in the diet, with a small proportion of hunted 
game, mainly of antelope and deer (Korisettar et al. 2001b). Evidence from recent context-based analysis, including evidence for burning and cutmarks, suggests that caprines may have been the mainstay of the diet, with cattle restricted to larger consumption events (feasts) (Boivin et al. 2005, 74-5; S. Meece pers. comm.). These subsistence data suggest household or kin-group based production strategies rather than specialisation between households, while the cattle evidence suggests some interhousehold communal consumption events, which might have coincided with periodic communal axe mass-production episodes on the one hand and ashmound conflagration events on the other (though these events need not have been contemporary).

A further outcome of the limited division of tasks is the importance of unskilled flaking procedures apparent on axe blanks. Even the prismatically shaped dolerite blocks could be worked by knappers with little experience. Such an economic pattern implies that the intensification of production taking place between c. 1750-1250/1200 cal BCE was not achieved through an increase in efficiency, but rather through the larger number of people participating in the manufacturing process. Under such circumstances, raw material scarcity cannot have been a relevant economic consideration at that time.

One exception in this general tendency seems to have been the preparation of long cylindrical chisel blanks. Survey and excavation data suggest that these tools were flaked and probably polished by highly skilled knappers working (and living?) in Area A of Hiregudda, more precisely in the area dominated by Feature 1. Otherwise, economic differences between the settlements were restricted to the relative importance of the different activities in the communities. In the occupation areas close to the dolerite dyke, time was devoted to the preparation of axe blanks, while at a greater distance, subsistence production and possibly the production of other types of object was more relevant.

The final polishing of the axe edges was carried out in a special area located on the plain and separated from the hill settlements and the dolerite dyke. Covered with over 100 narrow grooves, this area must have represented a particular place of production, but possibly also of communication and exchange with other communities. However, a large proportion of the axes must have left Sanganakallu in an unfinished state. Axe blanks of similar shape, rock texture and colour have been found in other prehistoric sites of the Deccan, where evidence of flaking is absent or marginal. One example is Piklihal, located c. $100 \mathrm{~km}$ north-west of the Hiregudda outcrop, where 14 axe and chisel blanks and 29 dolerite flakes were found (Allchin 1960). The flakes seem to have originated from broken axes or the reworking of axes. Similar evidence is reported from Budihal (Paddayya 2001, 198).

The existence of a large-scale distribution network for blanks and finished tools (the existence and precise organisation of which still needs to be investigated) also agrees with the scale of the quarrying and knapping activities identified in the SanganakalluKupgal complex. Moreover, the absolute chronology has confirmed that the phase of intense production only lasted a few centuries, between c. 1500-1250/1200 cal BCE, i.e. the time that corresponds to the transition between the local Neolithic and the Iron Age. The expected wider economic implications of such a marked intensification in the production of wood-cutting and wood-working instruments are increased land clearance, expansion of agricultural land, and demographic growth in the Deccan. The appearance of copper ornaments and weapons, and textile manufacture, all starting 
before $c .1500$ BCE, with the addition of tree crops, wheel-finished pottery and iron by $1200 \mathrm{BCE}$, also hints at a time of economic as well as social change (Fuller et al. 2007). So far the distribution of working instruments, as well as of highly valuable objects, such as stone, shell and metal beads, in the Sanganakallu-Kupgal area does not allow us to relate this production increase to a clear social differentiation between as well as inside the studied settlements. As can also be observed in other geographical and historical contexts, a qualitative change in the social relations and the appearance of a dominant class frequently takes place only after society has gone through a phase of economic intensification. In this sense, the appearance of Megalithic burials by 13001200 BCE probably testifies that the emergence of social and political elites coincided with the conclusion of large-scale axe production activities at Hiregudda.

\section{Acknowledgements}

This research programme has received support from the British Academy, Arts and Humanities Research Council, McDonald Institute for Archaeological Research, Leverhulme Trust, Karnatak University and the Generalitat de Catalunya. We are grateful to B. Janardhana, Subhas Chincholi, H.M. Anitha, Deepak Havanur, K. Linganna, K. Udayashankar, Lindsay Lloyd-Smith, Kalyan Malagyannavar, Paul Masser, Stephanie Meece, Pragnya Prasanna, Shankar Pujar, Arun Raj, Ramadas, and Paula Whittaker for their efforts during fieldwork. We are especially grateful to Jinu Koshy and Adam Brumm for their contributions to the study of the flaked material, and to Nick Drake, who studied the dykes, their weathering and their geology. 


\section{Bibliography}

Allchin, F.R. 1957 'The ground stone industry of the North Karnataka region', Bulletin for the School of Oriental and African Studies 19(2), 321-35.

Allchin, F.R. 1960 Piklihal Excavations, Archaeological Series No. 1, Hyderabad: Andhra Pradesh Government Publications.

Allchin, F.R. 1963 Neolithic Cattle Keepers of South India: a Study of the Deccan Ashmounds, Cambridge: Cambridge University Press.

Ansari, Z.D. and Nagaraja Rao, M.S. 1969 Excavations at Sanganakallu - 1964-65, Poona: Deccan College.

Boivin, N. 2004a 'Landscape and cosmology in the south Indian Neolithic: new perspectives on the Deccan ashmounds', Cambridge Archaeological Journal 14(2), 23557.

Boivin, N. 2004b 'Rock art and rock music: petroglyphs of the South Indian Neolithic', Antiquity 78(229), 38-53.

Boivin, N., Korisettar, R., Venkatasubbaiah, P.C., Lewis, H., Havanur, D., Malagyannavar K. and Chincholi, S. 2002 'Exploring Neolithic and Megalithic South India: the Bellary District Archaeological Project', Antiquity 76, 937-8.

Boivin, N., Korisettar, R. and Fuller, D.Q. 2005 'Further research on the Southern Neolithic and the Ashmound tradition: the Sanganakallu-Kupgal Archaeological Research Project, interim report', Journal of Interdisciplinary Studies in History and Archaeology 2(1), 63-92.

Boivin, N., Brumm, A., Lewis, H., Robinson, D. and Korisettar, R. 2007 'Sensual, material and technological understanding: exploring prehistoric soundscapes in south India', Journal of the Royal Anthropological Institute 13(2), 267-94.

Bradley, R. and Edmonds, M. 1993 Interpreting the Axe Trade: Production and Exchange in Neolithic Britain, Cambridge: Cambridge University Press.

Brumm, A., Boivin, N. and Fullager, R. 2006 'Signs of life: engraved stone artefacts from Neolithic south India', Cambridge Archaeological Journal 16(2), 165-90.

Brumm, A., Boivin, N., Korisettar, R., Koshy, J. and Whittaker, P. 2007 'Stone axe technology in Neolithic south India: new evidence from the Sanganakallu-Kupgal Region, mid-eastern Karnataka', Asian Perspectives 46(1), 65-95.

Davis, M. 2001 Late Victorian Holocausts. El Niño Camines and the Making of the Third World. London: Verso Books.

Delage, J.Ph. 2004 Les ateliers de taille néolothiques en Bergaracois. Toulouse: Ecole des Hautes Etudes en Sciences Sociales. 
Fawcett, F. 1892 'Pre-historic rock pictures near Bellary, South India', Imperial and Asiatic Quarterly Review (n.s.) 3, 147-57.

Foote, R.B. 1887 'Notes of some recent Neolithic and Palaeolithic finds in the South', Journal of the Asiatic Society of Bengal LVI(2), 259-82.

Foote, R.B. 1916 The Foote Collection of Indian Prehistoric and Protohistoric Antiquities: Notes on their Ages and Distribution. Madras: Madras Government Museum.

Fuller, D.Q. 2006 'Agricultural origins and frontiers in South Asia: a working synthesis', Journal of World Prehistory 20, 1-86.

Fuller, D.Q. and Korisettar, R. 2004 'The vegetational context of early agriculture in South India', Man and Environment 29(1), 7-27.

Fuller, D.Q., Korisettar, R. and Venkatasubbaiah, P.C. 2001 'Southern neolithic cultivation systems: a reconstruction based on archaeobotanical evidence', South Asian Studies 17, 171-87.

Fuller, D.Q., Korisettar, R. Venkatasubbaiah P.C. and Jones, M.K. 2004 'Early plant domestications in southern India: some preliminary archaeobotanical results', Vegetation History and Archaeobotany 13, 115-29.

Fuller, D.Q., Boivin, N. and Korisettar, R. 2007 'Dating the Neolithic of South India: new radiometric evidence for key economic, social and ritual transformations', Antiquity 81, 755-78.

Johansen, P.G. 2004 'Landscape, monumental architecture, and ritual: a reconsideration of the South Indian ashmounds', Journal of Anthropological Archaeology 23, 309-30.

Kennedy, R. 1962 "'Grinding benches" and mortars on Fernando Po', Man 62, 129-31.

Kenoyer, J.M., Vidale, M. and Bhan, K.K. 1991 'Contemporary stone beadmaking in Khambhat, India: Patterns of craft specialization and organization of production as reflected in the archaeological record', World Archaeology 23, 44-63.

Korisettar, R., Venkatasubbaiah, P.C. and Fuller D.Q. 2001a 'Brahmagiri and beyond: the archaeology of the Southern Neolithic' in S. Settar and R. Korisettar (eds) Indian Archaeology in Retrospect (Volume I, Prehistory), New Delhi: Manohar. 151-238.

Korisettar, R., Joglekar, P.P., Fuller, D.Q. and Venkatasubbaiah, P.C. 2001b 'Archaeological re-investigation and archaeozoology of seven Southern Neolithic sites in Karnataka and Andhra Pradesh', Man and Environment 26, 47-66.

Le Roux, C.T. 2002 'Plussulien et la diffusion des haches polies armoricaines' in J. Guilaine (ed) Matériaux, productions, circulations du Néolithique à l'Age du Bronze, Paris: Errance. 101-12. 
McCarthy, F.D. 1976 Australian Aboriginal Stone Implements, Sydney: The Australian Museum Trust.

Paddayya, K. 2001 'The problem of ashmounds of Southern Deccan in the light of the Budihal excavations, Karnataka', Bulletin of the Deccan College Post-Graduate and Research Institute 60-61, 189-225.

Pétrequin, P. and Jeunesse, C. 1995 La hache de pierre. Carrières vosgiennes et échanges de lames polies pendant le Néolithique (5400-2100 a.J.C.), Paris: Editions Errance.

Pétrequin, P., Errera, M., Pétrequin, A-M. and Allard, P. 2006 'The Neolithic quarries of Mont Viso, Piedmont, Italy: initial radiocarbon dates', European Journal of Archaeology 9(1), 7-30.

Pigeot, N. 1987 Magdaléniens d'Etiolles: économie de debitage et organisatin sociale (l'unité d'habitation U5), Ed. du CRNS Paris.

Shaw, C.T. 1944 'Report on excavations carried out in the cave known as "Bosumpra" at Abetifi, Kwahu, Gold Coast Colony', Proceedings of the Prehistoric Society 20, 1-67.

Stout, D. 2002 'Skill and cognition in stone tool production: an ethnographic case study from Irian Java', Current Anthropology 43, 693-722.

Subbarao, B. 1947 'Archaeological explorations in Bellary', Bulletin of the Deccan College Research Institute 8, 209-24.

Subbarao, B. 1948 Stone Age Cultures of Bellary, Poona: Deccan College.

Risch, R. 2002 Recursos naturales, medios de producción y explotación social. Un análisis económico de la industria lítica de Fuente Alamo (Almería), 2250-1400 ANE, Mainz Ph. von Zabern.

Risch, R. 2008 'From production traces to social organisation: towards an epistemology of functional analysis' in L. Longo and N. Skakun (eds) 'Prehistoric Technology' 40 years later: Functional Studies and the Russian Legacy. Museo Civico di Verona and Università degli Studi di Verona: Brit. Archaeol. Rep. Int. Ser. 1783, 513-21. 